\title{
The Whaling Dispute in the South Pacific: A Japanese Perspective
}

\section{Ad hoc Editorial Chamber*}

Australia instituted proceedings against Japan before the International Court of Justice alleging that the JARPA II is violating the obligation of ICRW which prohibits the commercial whaling. Japan is strongly protesting against Australia arguing that the JARPA II has been carried out only for research whaling. This paper contains the Japan's position over the whaling in the South Pacific. The Japan's arguments are divided into two sections in this paper. First, it will check if whales are truly vulnerable following the Comprehensive Assessment of the IWC. Second, it argues the legitimacy of the JARPA II under international law.

\section{Keywords}

JARPA II, Minke Whale, ICRW, IWC, Schedule, ICJ

\section{Introduction}

On May 31, 2010, Australia instituted proceedings against Japan before the International Court of Justice. ${ }^{1}$ Australia alleged that: "Japan's continued pursuit of a large scale program of whaling under the Second Phase of its Japanese Whale Research Program under Special Permit in the Antarctic ("JARPA II") [is] in breach of obligations assumed by Japan under the International Convention for the Regulation of Whaling ("ICRW"), as well as its other international obligations for the preservation of marine mammals

* This paper has been written by Ad hoc Editorial Chamber consisting of Professors Hyun-soo Kim, Eric Yong Joong Lee and John Riley. Japanese sources have been translated by Ms. Song-yi Kim.

1 In accordance with Article 36, paragraph 2, of the ICJ Statute, Australia and Japan recognized the Court's jurisdiction as compulsory on March 22, 2002 and July 9, 2007, respectively. 
and marine environment." 2 The case was based on the decision of the Federal Court of Australia on January 15, 2008, which adjudicated that Japan's whale research program conducted in the Antarctic Ocean should be illegal and ordered to cease it. ${ }^{3}$

The Application contends, in particular, that Japan "has breached and is continuing to breach the following obligations under the ICWR: (1) to observe in good faith the zero catch limit in relation to the killing of whales for commercial purposes; 4 and (2) to act in good faith to refrain from undertaking commercial whaling of humpback and fin whales in the Southern Ocean Sanctuary." 5 Australia points out that:

$[\mathrm{H}]$ aving regard to the scale of the JARPA II programme, the lack of any demonstrated relevance for the conservation and management of whale stocks, and to the risks presented to targeted species and stocks, the JARPA II programme cannot be justified under Article VIII of the ICRW.6

It further argues that Japan has also breached and is continuing to breach, inter alia, its obligations under the Convention on International Trade in Endangered Species of Wild Fauna and Flora( "CITES") and under the Convention on Biological Diversity( "CBD").7

\section{Legal Issues}

Australia requests the Court to declare that "Japan is in breach of its international obligations in implementing the JARPA II program in the Southern Ocean," and order Japan to: "(a) cease implementation of JARPA II; (b) revoke any authorisations, permits or licences allowing the activities which are the subject of this application to be undertaken; and (c) provide assurances and guarantees that it will not take any further action under the JARPA II or any similar program until such program has been brought into conformity with its obligations under international law." 8 Australia also explains

ICJ, Australia institutes proceedings against Japan for alleged breach of international obligations concerning whaling, Press RelEASE, June 1, 2010, available at http://www.icj-cij.org/docket/files/148/15953.pdf (last visited on Oct. 15, 2011)

3 Federal Court of Australia, Humane Society International Inc. v. Kyodo Senpaku Kaisha Ltd. [2008] FCA 3, NSD 1519 of 2004 (Jan. 15, 2008)

ICRW Schedule, para. 10 (e).

Id. para. 7 (b).

Supra note 2.

Id.

Id. 
that it has consistently opposed the JARPA II, both through individual protests and demarches, and relevant international forums, including the International Whaling Commission ("IWC"). 9

The most critical issue in this case is whether the JARPA II constitutes commercial whaling prohibited by the ICRW. In 1982, the IWC adopted a "moratorium of commercial whaling."10 Following the decision of the IWC, in 1985, Japan quit commercial whaling. In the 1987/88 season, however, Japan began the JARPA I based on Article VIII of the ICRW,11 which allows research whaling. The JARPA II was launched in 2005 as a new and expanded program. It is a long-term research program with the following objectives: 1) monitoring of the Antarctic ecosystem (whale abundance trends and biological parameters; drill abundance and the feeding ecology of whales; effects of contaminants on cetaceans; cetacean habitat); 2) modeling competition among whale species and future management objectives (constructing a model of restoration of the cetacean ecosystem); 3) elucidation of temporal and spatial changes in stock structure; and 4) improving the management procedure for the Antarctic minke whale stocks. ${ }^{12}$ In particular, the JARPA II places emphasis on collecting data that is necessary to establish a multi-species management model of whaling based on an ecosystem approach. The results of the JARPA II have not yet been reviewed since it has still in progress.

According to Australia, more than 6,800 minke whales were killed by the JARPA in the Southern Ocean for the period of 2004-5. Australia's argument is primarily based on the premise that the JAPRA is a commercial whaling program. However, the ICRW does not provide any definition on either commercial or research whaling. In this case, eventually, Australia should prove that the JARPA is commercial whaling.

9 Young-kil Park, Australia institutes proceedings against Japan on whaling: Legal Issues(available only in Korean), 10 JoURNAL OF DoKDo STUDIES 111-115 (2010), available at http://www.ilovedokdo.re.kr/Uploaded_Files/journal/ \%C6\%E4\%C0\%CC\%C1\%F6_\%20\%B5\%B6\%B5\%B5\%C0\%FA\%B3\%CE-\%BF\%A9\%B8\%A7\%C8\%A3-\%B1\%DB\%B7\%CE\% $\mathrm{B} 9 \% \mathrm{FA} \% \mathrm{BF} \% \mathrm{C} 0 \% \mathrm{BC} \% \mathrm{C} 7 \% \mathrm{C} 6 \% \mathrm{~F} 7 \% \mathrm{C} 4 \% \mathrm{BF} \% \mathrm{BD} \% \mathrm{BA}-4 . p d f$ (last visited on Oct. 15, 2011).

10 Supra note 4.

11 It reads: "Notwithstanding anything contained in this Convention any Contracting Government may grant to any of its nationals a special permit authorizing that national to kill, take and treat whales for purposes of scientific research subject to such restrictions as to number and subject to such other conditions as the Contracting Government thinks fit, and the killing, taking, and treating of whales in accordance with the provisions of this Article shall be exempt from the operation of this Convention. Each Contracting Government shall report at once to the Commission all such authorizations which it has granted. Each Contracting Government may at any time revoke any such special permit which it has granted."

12 See IWC Document, SC/57/01: Plan for the Second Phase of the Japanese Whale Research Program under Special Permit in the Antarctic (JARPA II) - Monitoring of the Antarctic Ecosystem and Development of New Management Objectives for Whale Resources (Government of Japan). 


\section{Japan's Arguments}

\section{A. Are Whales really Vulnerable in the South Pacific?}

Recently, there have been strong objections to Japanese research activities regarding whales. In principle, Japan is open to good faith discussions.

If the protest is along the lines of "protect the endangered whale species," Japan is on the same ground. Japan strongly supports the international protection of endangered whale species such as blue whales. According to Japan's whale research (as of 2002), Japan truly involves an annual maximum sampling of 590 minke whales, 50 Bryde's whales, 50 Sei whales and 10 sperm whales. 13 However, this level of sampling does not pose any risk to the current status of whale stocks. Following the evaluation of the IWC's Scientific Committee in 1990, minke whales had a population of 761,000 in the Antarctic Ocean. Also, in the Western North-Pacific Ocean, they have a population of 25,000. Bryde's whales, sperm whales and Sei whales have populations of 22,000, 102,000 and 28,000 , respectively. Thus, they are by no means endangered.14 Japan is rather concerned that certain NGOs and the media are spreading misinformation on this issue to the public to provoke an emotional reaction against their activities, which could make dialogue difficult. 15

The IWC adopted a moratorium on commercial whaling in 1982 with a proviso that "by 1990 at the latest, the Commission will undertake a Comprehensive Assessment ("CA") of the effects of this decision on whale stocks and consider modification of this provision and the establishment of other catch limits." The IWC Scientific Committee now agrees on the estimates resulting from the Comprehensive Assessment that at least 760,000 minke whales exist in the Antarctic and 25,000 in the Okhotsk Sea and WestNorth Pacific. Against this background, Japan has been asking the IWC to grant its coastal whalers an interim relief allocation of 50 minke whales per annum from this stock. 16

In 1994, the IWC adopted the Revised Management Procedure ("RMP") developed by its Scientific Committee. The RMP is a management tool for setting catch quotas for whale stocks at sustainable levels without risk to their populations. Simulation trials

\footnotetext{
13 Ministry of Foreign Affairs of Japan ("MOFA"), The Position of the Japanese Government on Research Whaling, available at http://www.mofa.go.jp/policy/q_a/faq6.html (last visited on Oct. 15, 2011).

14 Id.

15 Id.

16 MOFA, Japan's Request for a Catch of 50 Minke Whales in its Coastal Waters is Justifiable, available at http://www.mofa.go.jp/ policy/economy/fishery/whales/iwc/request.html (last visited on Oct. 15, 2011).
} 
using the RMP for Antarctic minke whales conducted by the Scientific Committee have revealed that 200,000 animals may be taken over 100 years without risk or harm to the population. However, the RMP has not been implemented because the development of an administrative scheme called the RMS is not yet completed. 17

Japan has a long history and culture associated with coastal whaling dating back more than 2,000 years. Since the IWC moratorium on commercial whaling came into effect, Japan's coastal whalers have been catching Baird's beaked whales and pilot whales. These species do not come under the jurisdiction of the IWC. Small-type coastal whaling, though limited in scale, is of economic importance to local communities. Small-type coastal whaling in Japan also has social and cultural significance similar to that of communities engaged in aboriginal subsistence whaling elsewhere in the world.

Today, there are at least 68 species of small cetaceans commonly known as dolphins and porpoises. Some countries have proposed that the IWC assume authority for their conservation and management. However, this proposal is unrealistic for two reasons. First, small cetaceans are distributed widely over the world's oceans; they occur in the waters of some 140 coastal States, far exceeding the 40 members of the IWC. The distribution of small cetaceans is also characterized by regional concentrations. Second, the IWC does not have the resources in terms of time, money or manpower, to conduct the research needed to regulate so many species. The IWC worked for many years just to complete the Comprehensive Assessment of a few large whale species. Partly recognizing the IWC's limited capabilities, in 1992, four North Atlantic nations established the North Atlantic Marine Mammal Commission ("NAMMCO") to manage cetaceans in the region. Japan believes that similar regional organizations are needed in the Pacific and elsewhere. 18

Today, there are more than 10 million whales throughout the world. The quantity of marine living resources whales consume is estimated to be some 180 million tons a year in the Antarctic alone and 500 million tons in all the oceans of the world combined. This represents approximately five times as much as the total of the resources now being harvested by the world's marine fisheries (90 million tons). 19

Biased protection of some selected species (i.e. whales) will cause disruption in the balance of the ecosystem and lead to a decline in the amount of marine living resources that could be used as food for the human population.

17 MOFA, Minke Whale Population in the Antarctic Estimated at 760,000, available at http://www.mofa.go.jp/policy/ economy/fishery/whales/iwc/population.html (last visited on Oct. 15, 2011).

18 MOFA, Management of Dolphins and Porpoises: Better Management by Regional Organizations, available at http://www.mofa.go.jp/policy/economy/fishery/whales/iwc/dolphin.html (last visited on Oct. 15, 2011).

19 MOFA, Whaling Moratorium and Southern Ocean Sanctuary Cause Waste of Resources, available at http://www.mofa.go.jp/ policy/economy/fishery/whales/iwc/moratorium.html (last visited on Oct. 20, 2011). 


\title{
B. Is the JARPA Commercial Whaling?
}

The moratorium of commercial whaling in Paragraph 10(e) of the Schedule reads as follows:

\begin{abstract}
Notwithstanding the other provisions of paragraph 10, catch limits for the killing for commercial purposes of whales from all stocks for the 1986 coastal and the 1985/86 pelagic seasons and thereafter shall be zero. This provision will be kept under review, based upon the best scientific advice, and by 1990 at the latest the Commission will undertake a comprehensive assessment of the effects of this decision on whale stocks and consider modification of this provision and the establishment of other catch limits. ${ }^{20}$
\end{abstract}

Japan is opposed to decisions on the commercial whaling moratorium and the Southern Ocean whale sanctuary, which are designed to prohibit the use of abundant whale species. Japan is proposing the sustainable harvesting of minke whales whose population is estimated to be over 760,000 in the Antarctic alone.21 To that end, Japan presented an objection against the amendment of the Schedule due to the lack of scientific grounds for a total ban of commercial whaling. 22 Not all species were in danger, as aforementioned. 23 Nonetheless, Japan withdrew its objection mainly as a result of external pressure and suspended commercial whaling in 1988.24 Furthermore, Paragraph 10(e) explicitly requires the IWC to undertake a comprehensive assessment and to establish appropriate catch limits within a period of ten years. Thus, Paragraph 10(e) provides for a measure to achieve scientifically sound and appropriate utilization of resources. The Japanese government deeply regrets that the moratorium has not been appropriately reconsidered by the IWC in accordance with Paragraph 10(e). ${ }^{25}$ The Japanese government has stated an intention to accept a practical, effective and costefficient monitoring and inspection scheme. Such a scheme would necessarily include national inspectors and international observers to verify catches, a conservative harvesting quota, and a fair sharing of the costs. Japan has tried to make substantial

20 international/en/about/history/Victories-timeline/whaling-moratorium (last visited on Oct. 20, 2011).

21 Supra note 19.

22 Donald K. Anton, Dispute Concerning Japan's JARPA II Program of "Scientific Whaling" (Australia v. Japan), 14 AM. J. INT' L L., available at http://www.asil.org/files/insight100707pdf.pdf (last visited on Oct. 15, 2011).

23 For details, see The Institute of Cetacean Research, Japan not catching endangered whales (Mar. 1, 2002), available at http://www.icrwhale.org/eng/SEI.pdf (last visited on Oct. 15, 2011).

24 For details, see Animal Planet, Why did Japan withdraw its opposition to the moratorium on commercial whaling in 1986?, available at http://animal.discovery.com/tv/whale-wars/whaling/japan-withdraw-moratorium.html (last visited on Oct. 15, 2011).

25 Supra note 4. 
compromise to reach an agreement on a reasonable RMS and made proposals for the purposes. 26

The Japanese government issued a special permit of whale research programs in the Antarctic Ocean or the Western North Pacific in accordance with Article VIII (1) of the ICRW.27 The programs involve both lethal and non-lethal research techniques, such as sighting surveys and biopsy sampling. ${ }^{28}$ They have two objectives: one is to collect biological information on whales to promote their sustainable utilization; the second, to collect relevant information on interactions between whales and other parts of marine ecosystem.

The JARPA is not commercial whaling. The research employs both lethal and nonlethal methods; it is carefully designed by scientists to study the whale populations and ecological roles of the species. Japan limits the sample to the lowest possible number, which will still allow the research to derive meaningful scientific results. The research plan and its results are annually reviewed by the IWC Scientific Committee. The IWC has recognized that non-lethal methods would not be enough to carry out full research on minke whales swimming very fast. Nonetheless, Japan committed to strengthen nonlethal elements of the research. ${ }^{29}$ Therefore, the research on whales is not a violation or an abuse of a loophole in the international convention. Instead, this is a legitimate right of the contracting party under Article VIII of the ICRW.

There is an argument that the sale of whale meat is evidence of commercial whaling. Whale meat is sold in the market of Japan. However, this is a requirement set forth by Article VIII of the ICRW. Also, the sale of whale meat does not create any profit in Japan. A non-profit research institute, which carries out this research program, sells the by-product in order to cover a portion of its research costs.

It is overly simplistic and premature to conclude that the whole world opposes whaling. While anti-whaling nations support the moratorium on commercial whaling at the IWC, while other nations are of a different opinion. Recently, more nations have come to support the idea of "sustainable use of whales" at the IWC meetings. 30

Finally, Japan would like to point out that whaling is no longer an issue of species conservation as was the situation in the 1960s and 1970s. At that time, several whale

\footnotetext{
26 IWC, Chair's Report of the RMS Working Group Meeting(IWC/58/RMS 3), available at http://iwcoffice.org/_documents/ commission/RMSdocs/58RMS3.pdf (last visited on Oct. 15, 2011).

27 Supra note 11.

28 Institute on Cetaceans Research, JARPA II 第二期南極海鯨類捕獲調查, available at http://www.icrwhale.org/ pdf/090413ReleaseJp.pdf\#search= ‘第 2 期南極海鯨類捕獲調査 ( J A R P A II ) について’ (last visited on Oct. 15, 2011).

29 Id.

30 Supra note 12. See also Hatanaka Hiroshi, Is the sustainable use of whale resources possible? 鯨類の持續的利用は 可能か?, 23 AQUABIOLOGY 海洋と生物 269-271 (2001).
} 
species were over-harvested and effective measures to protect the endangered species were urgently called for. The IWC did an outstanding job on this subject in the mid1970 's to protect blue whales and other endangered species, and Japan highly appreciates these efforts. However, since the 1980s the situation has changed as nonendangered whale species also became protected by the IWC, despite the fact that the IWC Scientific Committee calculated that some whale species were quite abundant. In the 1990's, scientists calculated that the global whale population consumes 250-440 million metric tons of fish and crustaceans every year. This amount is 3-5 times as much as is fished by human beings in the world. The ecological relevance of the total protection of whales should be reviewed under these circumstances. Anti-whaling does not automatically mean 'green.'

The comprehensive picture of Japan's position on whaling used to be misinformed and misunderstood. Japan is always committed to participating in a constructive exchange of views on the whaling issue in good faith. 31

\section{Conclusion}

Whaling is a controversial issue in the international community. Anti-whaling protests in some western countries have a strong influence on the policymaking of their governments. However, the scientific research on whaling in Japan is much distorted by some NGOs and the media in many aspects. It would not be easy for Japan to persuade anti-whaling counties in the IWC. However, whales should be protected based on scientific ground and its sustainable use should be accepted considering that whales are a marine resource. Japan is maintaining this basic position.

Whaling is conducted all around the world. Whaling in the past was ruthless; its main purpose is to get whale oil. However, whaling is becoming more sustainable. Anti-whaling without scientific basis is to deny the cultural heritage and tradition of human society. The IWC Scientific Committee presumed that there were 25,000 minke whales in the Pacific Ocean. The anti-whaling countries are against even an interim allocation of 50 minke whales per annum for costal whalers.

Whale research is indispensable for sustainable use and management of cetaceans. Also, only abundant whales are object of this research. Japan has been and will be maintaining the legitimacy and necessity of research whaling under international law. ${ }^{32}$

$31 \quad I d$.

32 MOFA, Position of Ministry Foreign Affairs over Whaling 捕鯨に詨する外務省の立場, available at http://www.mofa.go.jp/ mofaj/gaiko/whale/tachiba.html (last visited on Oct. 15, 2011). 